\title{
White-tailed deer habitats in the central Black Hills
}

\author{
CHRISTOPHER S. DEPERNO, JONATHAN A. JENKS, STEVEN L. GRIFFIN, LESLIE A. RICE, AND KENNETH \\ F. HIGGINS
}

Authors are Deer Project Leader, Minnesota Department of Natural Resources, Farmland Wildlife Populations and Research Group, Madelia, Minn. 56062; Professor, Department of Wildlife and Fisheries Sciences, South Dakota State University, Brookings, S.D. 57007; Wildlife Biologist, South Dakota Department of Game, Fish and Parks, 3305 W. South Street, Rapid City, S.D. 57702: Retired Senior Wildlife Biologist, South Dakota Department of Game, Fish and Parks, 3305 W. South Street, Rapid City, S.D. 57702: Professor, South Dakota Cooperative Fish and Wildlife Research Unit, USGS-BRD, South Dakota State University, Brookings, S.D. 57007.

\section{Abstract}

White-tailed deer (Odocoileus virginianus dacotensis Zimm.) numbers in the central Black Hills have declined since the middle 1970s. Population status has been documented by a decline in hunter success, deer reproductive success, and fawn survival. Most management agencies believe habitat deterioration is the primary cause of population decline in the Black Hills. We evaluated habitat selection for a white-tailed deer herd in the central Black Hills of South Dakota and Wyoming. From July 1993July 1996, 73 adult and yearling doe and 12 adult and yearling buck white-tailed deer were radiocollared and visually monitored. Habitat information was collected at 4,662 white-tailed deer locations and 1,087 random locations. During winter, whitetailed deer selected ponderosa pine- (Pinus ponderosa $\mathrm{P}$. \& C. Lawson) deciduous and burned pine cover types. Overstoryunderstory habitats selected included pine/grass-forb, pine/bearberry (Arctostaphylos uva-ursi (L.) Spreng.), pine/snowberry (Symphoricarpos albus L.), burned pine/grass-forb, and pine/shrub habitats. Structural stages selected included saplingpole pine stands with $>\mathbf{7 0} \%$ canopy cover, burned pine saplingpole and saw-timber stands with $<\mathbf{4 0 \%}$ canopy cover. During summer, white-tailed deer selected pine-deciduous, aspen (Populus tremuloides Michx.), aspen-coniferous, spruce (Picea glauca (Moench) Voss), and spruce-deciduous cover types. Overstory-understory habitats selected included pine/juniper (Juniperus communis $\mathbf{L}$.), aspen/shrubs, spruce/juniper, and spruce/shrub habitats. Structural stages selected included pine, aspen, and spruce sapling pole stands with all levels $(0-40 \%$, 41-70\%, 71-100\%) of canopy cover. Results supported low habitat quality as a factor involved with the decline of the deer population. We recommend that habitat management techniques, such as aspen regeneration and prescribed burns, be used to improve the habitat base in the central Black Hills.

This study was supported by Federal Aid to Wildlife Restoration Fund, Project W-75-R through the South Dakota Department of Game, Fish and Parks (Study Numbers 7563 and 7564). D. Flory, J. McCormick, D. Knowlton, S. Clark, B. Bol, D. Beck, and B. A. Hippensteel provided field assistance. We thank L. D. Flake, M. K. Johnson, G. E. Larson, and J. Vandever for their review of this manuscript. T. Klinkner and J. Giudice provided editorial assistance. We wish to thank the USDA, Forest Service, Pactola and Harney Ranger Districts and all landowners that allowed access to their property throughout this study.

Manuscript accepted 7 Sep. 01

\section{Resumen}

El número de venados cola blanca (Odocoileus virginianus dacotensis Zimm.) del área central de Black Hills ha disminuido desde mediados de la década de los 70 's. El estado de la población ha sido documentado por una reducción en el éxito de la cacería, la reproducción exitosa del venado y la sobrevivencia de los cervatos. La mayoría de las agencias de manejo creen que el deterioro del hábitat es la causa principal de la disminución de la población en Black Hill. Evaluamos la selección de hábitat por un hato de venados cola blanca en la región central de Black Hill en South Dakota y Wyoming. De Julio de 1993 a Julio de 1996, a 73 hembras adultas y juveniles y 12 machos adultos y juveniles de venado cola blanca se les coloco un radiotransmisor y se monitorearon visualmente. La información del hábitat se colectó en 4,662 localidades de venado cola blanca y 1,078 localidades aleatorias. Durante el invierno, el venado cola blanca seleccionó los tipos de cobertura de pino ponderosa (Pinus ponderosa $\mathrm{P}$. \& C. Lawson) deciduo y quemados. Los hábitats con cobertura superior/inferior seleccionados incluyeron pino/zacate-hierba, pino/ "Bearberry"(Arctostaphylos uva-ursi (L.) Spreng.), pino/ "Snowberry" (Symphoricarpos albus L.), pino quemado/zacatehierba y pino/arbusto. Las etapas estructurales seleccionados incluyeron poblaciones de plántulas de pino con una cobertura de copa mayor al $70 \%$, poblaciones de plántulas de pino quemado y poblaciones de pino aserrado con menos del $40 \%$ de cobertura. Durante el verano, el venado cola blanca seleccionó coberturas del tipo pino-deciduo, álamo (Populus tremuloides Michx.), álamo-coníferas, pícea (Picea glauca (Moench) Voss) y píceadeciduo. Los hábitats de cobertura alta-baja seleccionados incluyeron hábitats de pino/enebro (Juniperus communis L.), álamo/arbustos, pícea/enebro y pícea/arbustos. Los niveles estructurales seleccionados incluyeron poblaciones de plántulas de pino, álamo y pícea con todos los niveles $(0-40 \%, 41-70 \%$, 71-100\%) de cobertura de copa. Los resultados apoyan la baja calidad del hábitat como un factor involucrado en la disminución de la población de venados. Recomendamos que técnicas de manejo del hábitat, tales como la regeneración del álamo y los fuegos prescritos, sean utilizadas para mejorar el hábitat base en la región central de Black Hills.

Key Words: aspen regeneration, Black Hills, habitat quality, habitat selection, Odocoileus virginianus dacotensis, prescribed burns, South Dakota, white-tailed deer, Wyoming 
White-tailed deer (Odocoileus virginianus dacotensis Zimm.) are an important economic resource within the Black Hills of South Dakota and throughout North America. Williamson and Doster (1981) estimated that each white-tailed deer in North America generates about \$1,657 per year through consumptive and non-consumptive uses. Restaurants, lodges, convenience stores, and gas stations receive income from visitors attempting to observe white-tailed deer (Martin and Gum 1978, Wallace et al. 1991). Annually, the Black Hills deer herd generates over $\$ 2$ million dollars, in addition to license fees (Richardson and Peterson 1974), with each resident hunter spending approximately $\$ 372 /$ year (United States Fish and Wildlife Service 1993).

White-tailed deer numbers in the central Black Hills have declined since the middle 1970's (Griffin et al. 1992, Griffin 1994) and DePerno (1998) estimated this population declined by $10-15 \%$ per year from 1993-1996. Population status has been documented by a decline in hunter success (McPhillips and Rice 1991), deer reproductive success (Rice 1984, Hauk 1987, McPhillips 1990), and fawn survival (Rice 1979). Additionally, because reproductive and recruitment rates have not increased with herd reductions, it appears that deer carrying capacity in the central Black Hills has declined (DePerno et al. 2000). Griffin et al. (1992) reported that most management agencies believe the low productivity affecting the central Black Hills deer herd was directly related to long-term habitat deterioration.

We evaluated habitat selection by whitetailed deer in the central Black Hills of South Dakota and Wyoming. Habitats are differentiated by tree size and amount of overstory cover present; characteristics that represent age and structural class of vegetation within forested areas (Smith 1962). Documentation of habitat use by bucks and does during winter and summer is necessary to develop area-specific strategies for maintaining deer populations. For example, in the northern Black Hills, many habitats used by white-tailed deer differ from their relative availability on summer and winter ranges (Kennedy 1992). During winter, Moen (1968, 1976) concluded that dense pine stands are important to deer; these stands minimize energy expenditures for thermoregulation by reducing windchill and radiant heat loss (Parker and Gillingham 1990). During spring and summer, because condition and type of cover used for fawning may influence the survival rate of fawns, does seek isolation in areas where hiding cover is abundant (King and Smith 1980, Fox and Krausman 1994). We hypothesized that white-tailed deer in the central Black Hills select habitats on summer range that contain abundant forage (stands with low overstory cover and significant shrub biomass) and cover (stands with high overstory cover and significant shrub biomass) necessary to enhance reproductive success, while selecting habitats on winter range that contain abundant forage and cover necessary to reduce thermal stress.

\section{Study Area}

The Black Hills is an isolated mountainous area in western South Dakota and northeast Wyoming that extends approximately $190 \mathrm{~km}$ north to south and $95 \mathrm{~km}$ east to west (Petersen 1984). Elevation of the Black Hills ranges from 973-2,202 $\mathrm{m}$ above mean sea level (Orr 1959, Turner 1974). Annual mean temperatures are typical of a continental climate and range from $5-9^{\circ} \mathrm{C}$ with extremes of $-40-44^{\circ} \mathrm{C}$ (Thilenius 1972). Mean annual precipitation ranges from $45-66 \mathrm{~cm}$ (Orr 1959) and yearly snowfall may exceed 254 $\mathrm{cm}$ at higher elevations (Thilenius 1972).

The central Black Hills study area $\left(43^{\circ} 52^{\prime} \mathrm{N}\right.$ to $44^{\circ} 15^{\prime} \mathrm{N}-104^{\circ} 07^{\prime} \mathrm{W}$ to $103^{\circ} 22^{\prime} \mathrm{W}$ ) includes Pennington and Lawrence counties of South Dakota and Crook and Weston counties of Wyoming (Fig. 1). The study area is composed of separate winter and summer ranges used by migratory white-tailed deer (DePerno 1998, DePerno et al. 2000, Griffin et al. $1995,1999)$. In the central Black Hills, typical autumn migration for white-tailed deer is in a 199.3-1996. southeast direction from high elevation summer ranges to low elevation winter ranges and generally occurs between August and February (DePerno 1998, Griffin et al. 1999). Typical spring migration is in a northwest direction from low elevation winter ranges to high elevation summer ranges and generally occurs between 17 and 23 May (DePerno 1998. Griffin et al. 1999). Public land within the study area is managed by the United States Department of Agriculture Forest Service, within the Pactola, Harney, and Elk Mountain Ranger Districts, primarily for timber production and livestock grazing (1 June-31 October).

Winter range consists primarily of monotypic stands of ponderosa pine (Pinus ponderosa P. \& C. Lawson) interspersed with stands of burned pine, quaking aspen (Populus tremuloides Michx.), and paper birch (Betula papyrifera Marsh.) (McIntosh 1949, Orr 1959,

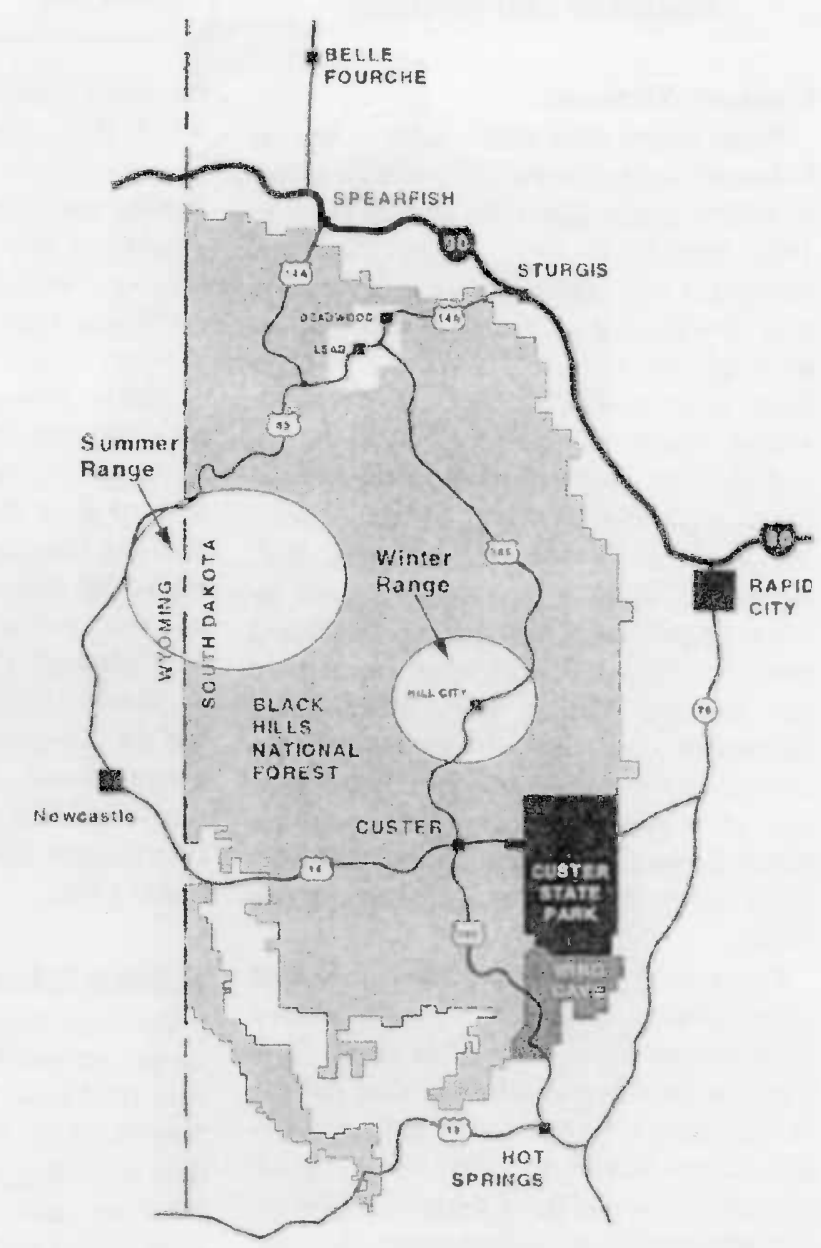

Fig. 1. Location of winter and summer ranges of white-tailed deer in the central Black Hills, South Dakota and Wyoming, 
Thilenius 1972, Richardson and Petersen 1974, Hoffman and Alexander 1987). Primary understory vegetation on winter range is characterized by snowberry (Symphoricarpos albus L.), spiraea (Spiraea betulifolia Pallas), serviceberry (Amelanchier alnifolia (Nutt.) Nutt. ex. M. Roemer), woods rose (Rosa woodsii Lindl.), bearberry (Arctostaphylos uvaursi (L.) Spreng.), and cherry species (Prunus spp.). Summer range consists primarily of ponderosa pine and white spruce (Picea glauca (Moench) Voss) interspersed with small stands of quaking aspen (McIntosh 1949, Orr 1959, Thilenius 1972, Richardson and Petersen 1974, Hoffman and Alexander 1987). Understory vegetation on summer range is characterized by Oregon grape (Berberis repens Lindl.), juniper (Juniperus communis L.), bearberry, snowberry, spiraea, and serviceberry.

\section{Materials and Methods}

\section{Capture Methods}

White-tailed deer were captured during February and March 1993-1996 using modified, single-gate Clover traps (Clover 1956) baited with fresh alfalfa (Medicago sativa L.) hay. Deer were captured on 4 trap sites located northeast, northwest, and west of Hill City, S.D., on the McVey Burn deer winter range (Griffin et al. 1995). Adult and yearling doe $(n=73)$ and buck $(n=12)$ white-tailed deer were fitted with radiocollars (Telonics Inc., Mesa, Ariz.; Lotek Engineering, Inc. Ontario, Canada), ear-tagged, aged by lower incisor wear, and released. Captured fawn white-tailed deer were ear-tagged and released (Griffin et al. 1995). Each radiocollar used in this study contained a mercury tip switch that enabled determination of head-up and head-down position based upon signal intensity and differing pulse intervals (Beier and McCullough 1988).

From July 1993-July 1996, individual radiocollared deer were visually located from the ground 1-3 times per week. Deer were radiotracked at different time periods to maximize observations of diurnal activities (Kernohan et al. 1996) and to obtain adequate sample sizes without violating the assumption of independent observations (White and Garrott 1990). Kernohan et al. (1996) demonstrated no differences between diurnal and 24-hour habitat use

Appendix A. Common and scientific names of trees and shrubs included in the 'other shrubs' category.

$\begin{array}{ll}\text { Bearberry } & \text { Arctostaphylos uva-ursi ((L.) Spreng.) } \\ \text { Cherry species } & \text { Prunus spp. } \\ \text { Currants } & \text { Ribes spp. } \\ \text { Fleshy hawthorn } & \text { Crataegus succulenta (Shrad. ex Link) } \\ \text { Juniper } & \text { Juniperus communis (L.) } \\ \text { Leadplant } & \text { Amorpha canescens } \text { (Pursh) } \\ \text { Mountain balm } & \text { Ceanothus velutinus (Dougl. ex Hook.) } \\ \text { Mountain meadowsweet } & \text { Spiraea betulifolia (Pallas) } \\ \text { Oregon grape } & \text { Berberis repens (Lindl.) } \\ \text { Paper birch } & \text { Betula papyrifera } \text { (Marsh.) } \\ \text { Ponderosa pine } & \text { Pinus ponderosa } \text { (P. \& C. Lawson) } \\ \text { Quaking aspen } & \text { Populus tremuloides (Michx.) } \\ \text { Red raspberry } & \text { Rubus idaeus (L.) } \\ \text { Russet buffaloberry } & \text { Shepherdia canadensis ((L.) Nutt.) } \\ \text { Serviceberry } & \text { Amelanchier alnifolia ((Nutt.) Nutt. ex M. Roemer) } \\ \text { Snowberry } & \text { Symphoricarpos albus } \text { (L.) } \\ \text { Wartleberry } & \text { Vaccinium scoparium } \text { (Leib ex Coville) } \\ \text { White spruce } & \text { Picea glauca ((Moench) Voss) } \\ \text { Willow } & \text { Salix } \text { spp. } \\ \text { Woods rose } & \text { Rosa woodsii (Lindl.) } \\ \text { Yellow rose } & \text { Potentilla fruticosa ((Pursh) A. Love) }\end{array}$

for white-tailed deer. Within the central Black Hills, steep hills, deep draws, and long migration distances limited data collection activities to diurnal, visual observations of deer and prevented the use of other techniques (e.g., triangulation) for obtaining radiolocations. Furthermore, because of the terrain and inaccessibility of many areas, attempts at spotlighting radiocollared deer to obtain nocturnal data were inefficient and represented a bias toward deer that were more accessible. Activity (feeding and bedding) was determined by radio signal intensity and speed of the pulse intervals (Beier and McCullough 1988, Hansen et al. 1992, Weckerly 1993). Deer locations were plotted on 7.5-minute USGS topographical maps (scale, 1:24,000) and assigned Universal Transverse Mercator (UTM) coordinates (Edwards 1969, Grubb and Eakle 1988).

\section{Habitat Selection}

Because separate winter and summer ranges are used by migratory white-tailed deer (DePerno 1998, DePerno et al. 2000, Griffin et al. 1995, 1999), we stratified data according to seasonal elevation shifts made by each individual each year (Apps et al. 2001) and classified each deer location and the corresponding habitat information as either winter or summer range. Habitat information was collected from
400- $\mathrm{m}^{2}$, circular plots centered on each deer observation site (providing the location of the radiocollared deer was visually determined without disturbing the animal) and, to obtain a measure of relative habitat availability, at computer generated random locations (i.e., sampled throughout the study area) (Marcum and Loftsgaarden 1980, Kennedy 1992). General information recorded at each location included: UTM location (north and east), and dominant overstory tree species along with the most prominent understory vegetation. If $\geq 2$ tree species provided canopy cover, the species that provided the largest amount of cover was recorded as the primary forest species; remaining species were recorded as secondary species.

Additional habitat characteristics recorded at each location included: overstory canopy cover (\%), basal area $\left(\mathrm{m}^{2} / \mathrm{ha}\right)$, diameter at breast height $(\mathrm{DBH})$ $(\mathrm{cm})$, habitat association (pine, spruce, aspen), and vegetation structural stage. Percent overstory canopy cover was measured using a spherical densiometer (Lemmon 1956). Basal area, the cross sectional area of trees at breast height, was determined using a 10-factor angle gauge (Hovind and Reick 1970). Diameter at breast height of each tree included in the basal area count was measured, $1.37 \mathrm{~m}$ above the ground (Ford-Robertson 1971), to the nearest centimeter using a diameter tape. Vegetation structural stage units, 
Table 1. Percent forest type availability and use by doe and buck white-tailed deer during winter and summer in the central Black Hills, South Dakota and Wyoming, 1993-1996.

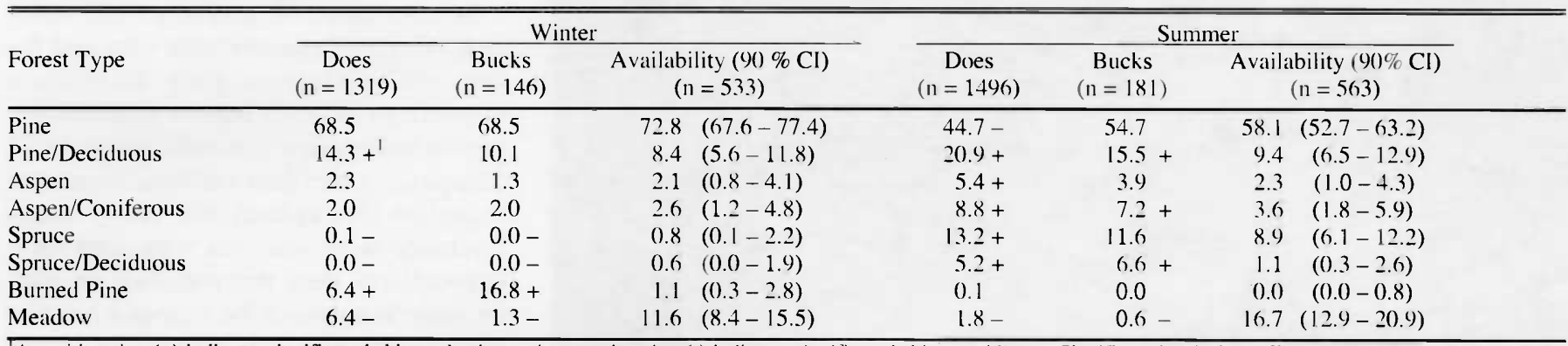

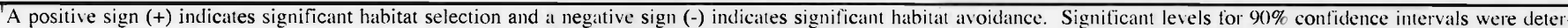
mined using the Bonferroni method (Neu et al. 1974, Byers et al. 1984).

which followed the Black Hills National Forest inventory system, were based on dominant overstory tree species, percent overstory canopy cover, and average DBH (Buttery and Gillam 1983, Rumble and Anderson 1992, 1993). Dominant tree species included ponderosa pine, spruce, and aspen. Meadow and burned pine habitats also were included. Pine, burned pine, spruce, and aspen stands were categorized based on stand age (Buttery and Gillam 1983). Structural stage categories included: $1=$ grass $/$ forb $-0 \mathrm{~cm} \mathrm{DBH;} 2=$ shrub/sapling - $<12.7 \mathrm{~cm} \mathrm{DBH;} 3=$ poletimber $-12.7-22.8 \mathrm{~cm} \mathrm{DBH}$, and $4=$ saw-timber - > $22.8 \mathrm{~cm}$ DBH. Structural stage categories 3 and 4 were further separated by percent canopy cover into: $\mathrm{A}=0$ $40 \%, \mathrm{~B}=41-70 \%$, and $\mathrm{C}=71-100 \%$ (e.g., A3B represents an aspen pole-stand with 41-70\% canopy cover) (Kennedy 1992, DePerno 1998).

The overstory-understory relationships for pine, spruce, and aspen associations were determined by combining overstory characteristics (i.e., dominant tree species present, percent overstory canopy cover, basal area, average DBH) with dominant understory species present. Dominant understory species were determined in 15 , $1-\mathrm{m}^{2}$ plots systematically spaced within the $400-\mathrm{m}^{2}$ area surrounding and including plot center (Daubenmire 1959, Kennedy 1992). Percent ground cover of grass, forbs, and shrubs $<1 \mathrm{~m}$ in height was visually estimated for each plot using the midpoint method as described by Daubenmire (1959).

\section{Analytical Methods}

Forest type, overstory-understory habitat, and structural stages were pooled across individuals, years, and activities by season. Deer locations were pooled for all

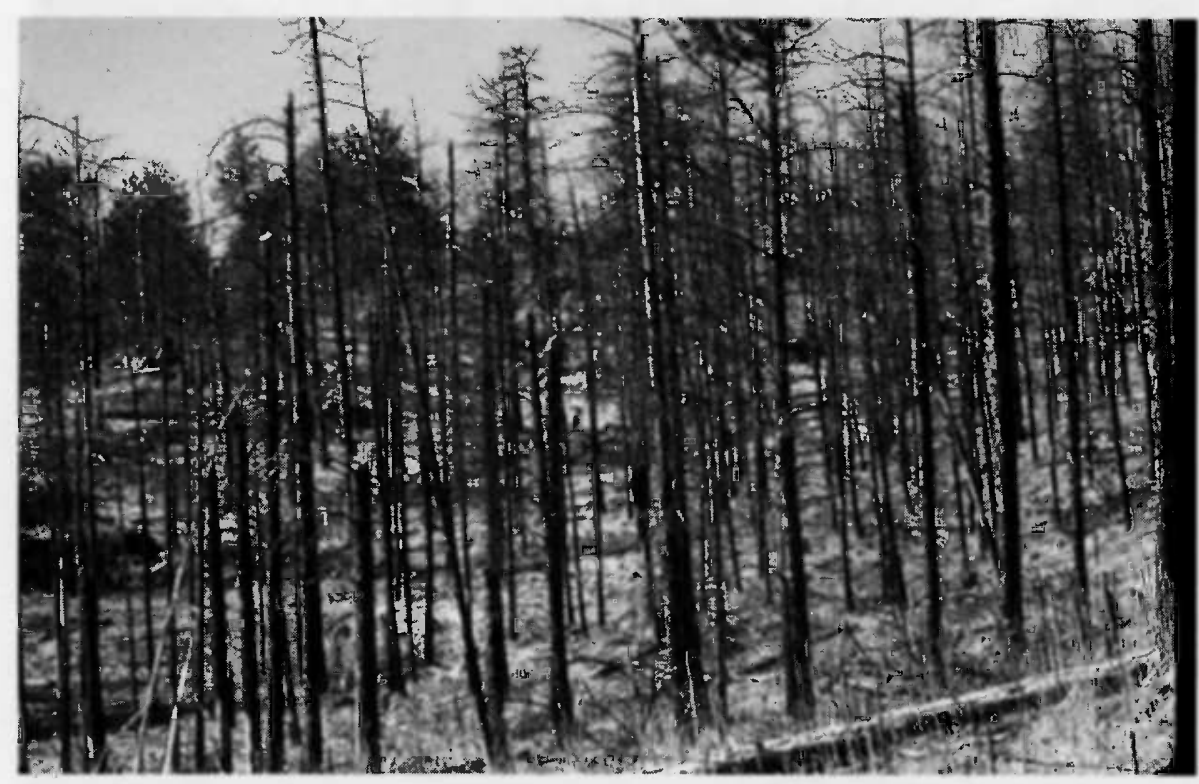

Fig. 2. Burned pine habitat on winter range in the central Black Hills, South Dakota and Wyoming, 1993-1996.

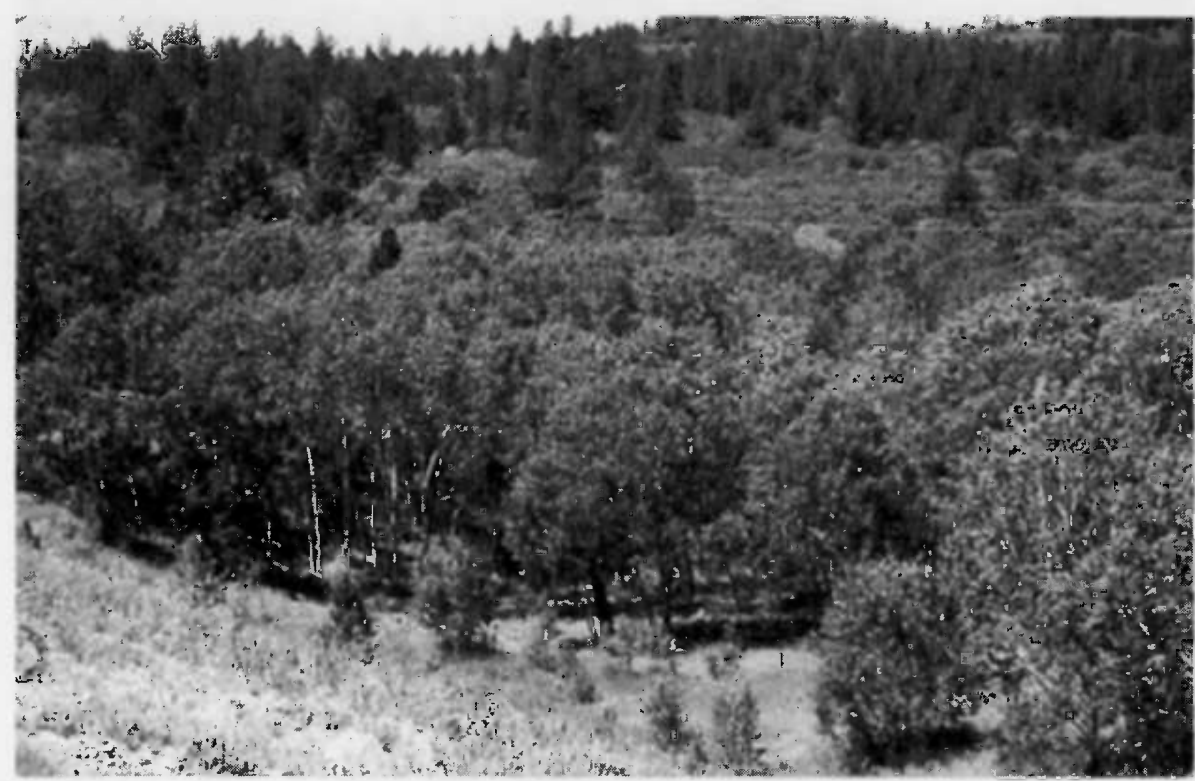

Fig. 3. Aspen habitat on summer range in the central Black Hills, South Dakota and Wyoming, 1993-1996. 


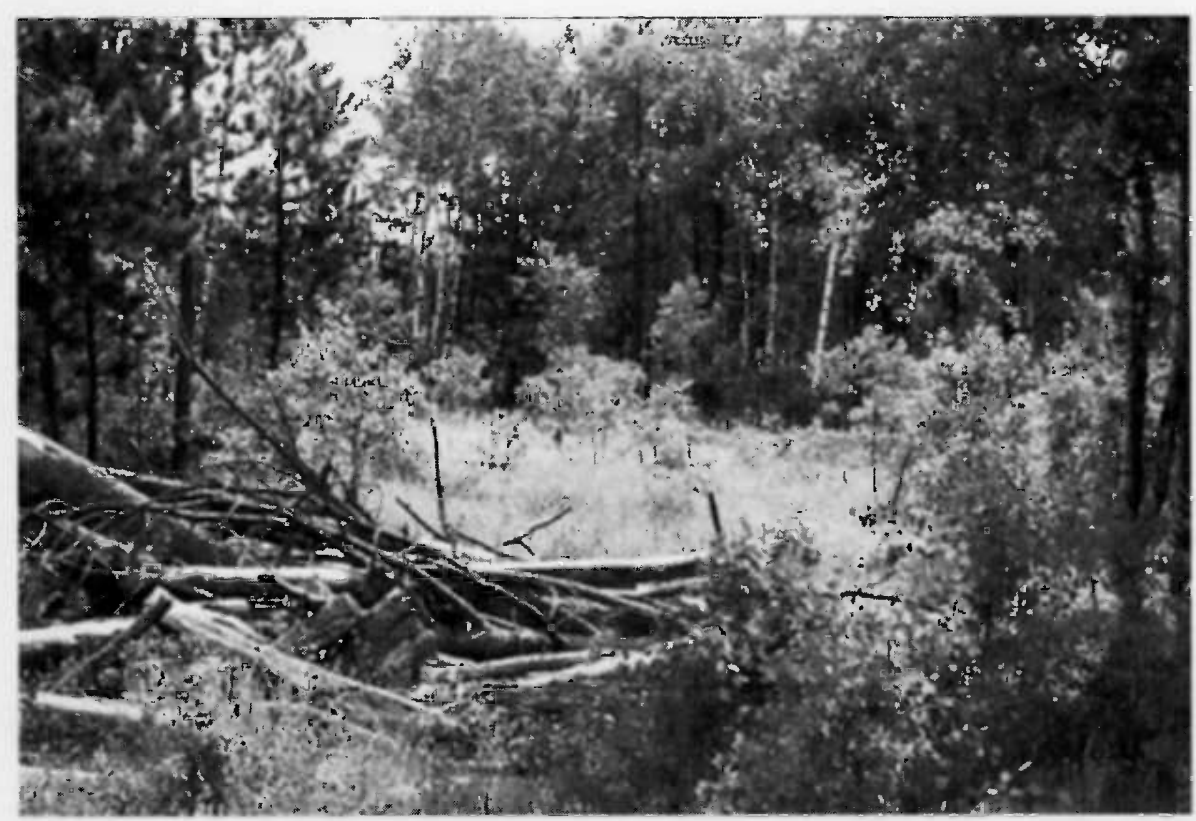

Fig. 4. Aspen/coniferous habitat on summer range in the central Black Hills, South Dakota and Wyoming, 1993-1996.

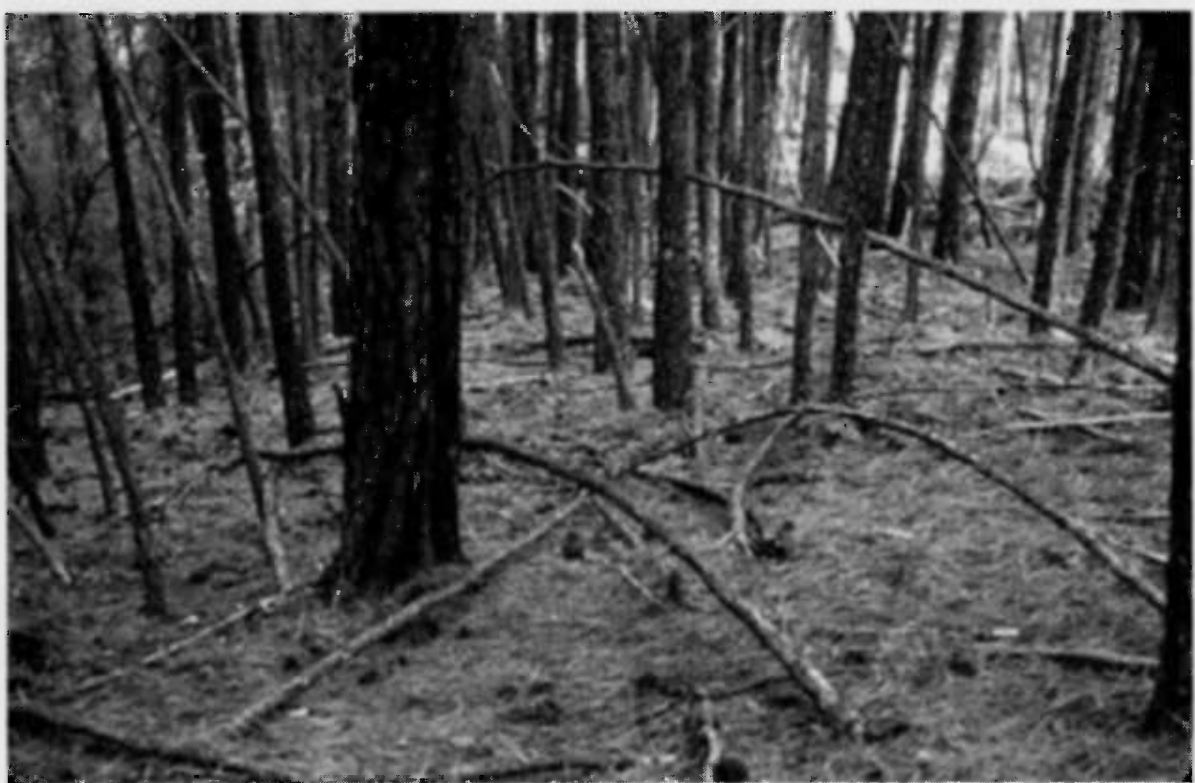

Fig. 5. Burned pine/litter habitat on winter range in the central Black Hills, South Dakota and Wyoming, 1993-1996.

years of the study because of high seasonal site fidelity (Progulske and Baskett 1958, Ozoga et al. 1982, Tierson et al. 1985. Kennedy 1992, Nelson 1995, Griffin et al. 1999). Because sufficient observations per animal $(\bar{x}=52.96 \pm 5.20)$ were recorded (Alldredge and Ratti 1986, 1992) and because habitat availability was assumed to be equal for all radiocollared animals. a chi-square test of homogeneity was used to determine differences between expected and observed distributions of forest type, overstory-understory habitat, and structural stage (Jelinski 1991, Kennedy

\section{Results}

Between July 1993 and July 1996, 4,089 and 573 radiolocations were obtained for does and bucks, respectively. To obtain a measure of relative habitat availability, habitat information was collected at 1,087 computer generated random locations sampled throughout the study area. Excluded from analyses were data on 1 radiocollared buck that remained on winter range throughout the year and 1 radiocollared doe that demonstrated an abnormal migration pattern (DePerno et al 1997).

\section{Forest Type}

Forest type availability varied between winter and summer ranges $\left(\chi^{2}=68.56, \mathrm{df}\right.$ $=7, \mathrm{P}<0.001)$, and use of forest types (Table 1) differed for does and bucks compared to forest type availability during winter $\left(\chi^{2}=66.59, \mathrm{df}=7, \mathrm{P}<0.001, \chi^{2}=\right.$ 72.03, $\mathrm{df}=7, \mathrm{P}<0.001)$ and summer $\left(\chi^{2}\right.$ $=238.77, \mathrm{df}=7, \mathrm{P}<0.001, \chi^{2}=30.32, \mathrm{df}$ $=7, \mathrm{P}<0.001)$.

During winter, pine/deciduous and burned pine forests (Fig. 2) were selected $(\mathrm{P}<0.05)$, whereas spruce, spruce/deciduous, and meadows were avoided $(P<$ 0.05 ) by does; remaining habitats were used in proportion to their availabilities. Buck use of burned pine forest was nearly 3-times that of does and buck use of pine/deciduous habitat was less $(\mathrm{P}<0.05)$ than does and not significantly different from its availability. During summer, pine/deciduous, aspen (Fig. 3), aspen/coniferous (Fig. 4), spruce, and spruce/deciduous habitats were selected $(P<0.05)$, whereas pine and meadow habitats were avoided $(\mathrm{P}<0.05)$ and burned pine was used in proportion to its availability by does. Bucks selected $(\mathrm{P}<0.05)$ pine/deciduous, aspen/coniferous, and spruce/deciduous habitats, while avoiding $(\mathrm{P}<0.05)$ meadows; remaining habitats were used in proportion to their availabilities. Overall, deer selected forest types that comprised only $10 \%$ of the winter range and $25 \%$ of the summer range.

\section{Overstory/Understory Type}

Availability of overstory-understory types differed $\left(\chi^{2}=58.89\right.$, df $=14, \mathrm{P}<$ $0.001)$ between summer and winter range. Overstory/understory use differed (Table 2) for does compared to availability during winter $\left(\chi^{2}=116.16\right.$, df $\left.=14, \mathrm{P}<0.001\right)$ 
Table 2. Percent overstory-understory availability and use by doe and buck white-tailed deer during winter and summer in the central Black Hills, South Dakota and Wyoming, 1993-1996.

\begin{tabular}{|c|c|c|c|c|c|c|c|}
\hline \multirow{3}{*}{$\begin{array}{l}\text { Forest Type } \\
\text { Pine/Grass/Forb }\end{array}$} & \multicolumn{4}{|c|}{ Winter } & \multicolumn{3}{|c|}{ Summer } \\
\hline & \multirow{2}{*}{$\frac{\begin{array}{c}\text { Does } \\
(\mathrm{n}=1000)\end{array}}{45.3+1}$} & \multirow{2}{*}{$\frac{\begin{array}{c}\text { Bucks } \\
(\mathrm{n}=124)\end{array}}{37.9+}$} & \multicolumn{2}{|c|}{$\begin{array}{l}\text { Availability }(90 \% \mathrm{CI}) \\
(\mathrm{n}=470)\end{array}$} & \multirow{2}{*}{$\begin{array}{c}\begin{array}{c}\text { Does } \\
(\mathrm{n}=1387)\end{array} \\
22.5-\end{array}$} & \multirow{2}{*}{$\frac{\begin{array}{c}\text { Bucks } \\
(\mathrm{n}=177)\end{array}}{32.8}$} & $\begin{array}{c}\text { Availability }(90 \% \mathrm{CI}) \\
(\mathrm{n}=466)\end{array}$ \\
\hline & & & 14.9 & $(10.7-19.7)$ & & & $37.1(31.0-43.3)$ \\
\hline Pine/Bearberry & $2.0+$ & $11.3+$ & 0.2 & $(0.0-1.6)$ & $5.8-$ & 9.0 & $9.4 \quad(6.1-13.6)$ \\
\hline Pine/Juniper & 0.0 & 0.8 & 0.0 & $(0.0-1.1)$ & $24.3+$ & $16.4+$ & $6.7 \quad(3.8-10.3)$ \\
\hline Pine/Snowberry & $10.1+$ & $1.6+$ & 0.2 & $(0.0-1.6)$ & 0.7 & 0.6 & $0.6 \quad(0.0-2.4)$ \\
\hline Burned Pine/Grass/Forb & $6.8+$ & $17.7+$ & 0.0 & $(0.0-1.1)$ & 0.1 & 0.0 & $0.0 \quad(0.0-1.1)$ \\
\hline Burned Pine/Litter & $25.4-$ & $22.6-$ & 78.7 & $(73.0-83.5)$ & $12.0-$ & $6.8-$ & $25.8(20.3-31.5)$ \\
\hline Pine/Other Shrubs ${ }^{2}$ & $5.4+$ & $4.0+$ & 0.2 & $(0.0-1.6)$ & 2.3 & $5.1+$ & $0.9 \quad(0.1-2.7)$ \\
\hline Aspen/Grass/Forb & 2.3 & 2.4 & 3.0 & $(1.2-5.7)$ & 8.6 & 7.9 & $(2.9-8.7)$ \\
\hline Aspen/Litter & 0.5 & 0.8 & 1.5 & $(0.3-3.6)$ & 1.0 & 0.6 & $(0.0-2.0)$ \\
\hline Aspen/Other Shrubs ${ }^{2}$ & 2.1 & 0.8 & 1.1 & $(0.2-3.0)$ & $3.8+$ & $2.8+$ & $(0.0-2.0)$ \\
\hline Spruce/Grass/Forb & 0.1 & 0.0 & 0.0 & $(0.0-1.1)$ & 7.6 & 7.4 & $(3.2-9.3)$ \\
\hline Spruce/Juniper & 0.0 & 0.0 & 0.0 & $(0.0-1.1)$ & $4.2+$ & $4.0+$ & $(0.1-2.7)$ \\
\hline Spruce/Wartleberry & 0.0 & 0.0 & 0.0 & $(0.0-1.1)$ & 3.1 & 1.7 & $(0.7-4.6)$ \\
\hline Spruce/Litter & 0.0 & 0.0 & 0.2 & $(0.0-1.6)$ & 2.2 & $1.7-$ & $(2.1-7.4)$ \\
\hline Spruce/Other Shrubs ${ }^{2}$ & 0.0 & 0.0 & 0.0 & $(0.0-1.1)$ & $2.0+$ & $3.4+$ & $(0.0-1.6)$ \\
\hline
\end{tabular}

${ }^{\mathrm{A}}$ A positive (+) sign indicates significant habitat selection and a negative sign (-) indicates significant habitat avoidance. Significance levels for $90 \%$ confidence intervals was determined using the Bonferroni method (Neu et al. 1974, Byers et al. 1984).

${ }^{2}$ See Appendix A for a list of other shrubs.

and summer $\left(\chi^{2}=203.11, \mathrm{df}=14, \mathrm{P}<\right.$ $0.001)$, and for bucks during winter $\left(\chi^{2}=\right.$ 65.31 , df $=14, \mathrm{P}<0.001)$. During summer, overstory-understory habitats used by bucks did not differ $\left(\chi^{2}=10.39, \mathrm{df}=14.0\right.$, $\mathrm{P}=0.73)$ from habitat availability.

During winter, pine/grass/forb, pine/bearberry, pine/snowberry, burned pine/grass/forb, and ponderosa pine/other shrubs (Appendix A) were selected $(\mathrm{P}<$ 0.05 ), whereas burned pine/litter (Fig. 5) was avoided $(\mathrm{P}<0.05)$ by does and bucks;

Table 3. Percent structural stage availability and use by doe and buck white-tailed deer during summer and winter in the central Black Hills, South Dakota and Wyoming, 1993-1996.

\begin{tabular}{|c|c|c|c|c|c|c|c|c|}
\hline \multirow{3}{*}{$\begin{array}{l}\text { Habitat }^{1} \\
\text { P3A }\end{array}$} & \multicolumn{4}{|c|}{ Winter } & \multicolumn{4}{|c|}{ Summer } \\
\hline & \multirow{2}{*}{$\begin{array}{c}\begin{array}{c}\text { Does } \\
(\mathrm{n}=477)\end{array} \\
9.6\end{array}$} & \multirow{2}{*}{$\begin{array}{c}\begin{array}{c}\text { Bucks } \\
(\mathrm{n}=47)\end{array} \\
4.3-\end{array}$} & \multicolumn{2}{|c|}{$\begin{array}{c}\text { Availability }(90 \% \mathrm{CI}) \\
(\mathrm{n}=532)\end{array}$} & \multirow{2}{*}{$\begin{array}{c}\begin{array}{c}\text { Does } \\
(\mathrm{n}=786)\end{array} \\
7.3\end{array}$} & \multirow{2}{*}{$\begin{array}{c}\begin{array}{c}\text { Bucks } \\
(\mathrm{n}=99)\end{array} \\
10.1+\end{array}$} & \multicolumn{2}{|c|}{$\begin{array}{c}\text { Availability }(90 \% \mathrm{CI}) \\
(\mathrm{n}=562)\end{array}$} \\
\hline & & & 8.5 & $(5.3-12.4)$ & & & 5.9 & $(3.3-9.2)$ \\
\hline P3B & 15.9 & $36.2+$ & 13.7 & $(9.6-18.4)$ & 10.8 & $13.1+$ & 7.7 & $(4.7-11.3)$ \\
\hline P3C & $22.2+{ }^{2}$ & $25.5+$ & 14.7 & $(10.5-19.5)$ & $10.4+$ & $12.1+$ & 4.8 & $(2.5-7.9)$ \\
\hline P4A & 10.9 & 10.6 & 9.2 & $(5.9-13.3)$ & 17.2 & $23.2+$ & 14.2 & $(10.2-18.9)$ \\
\hline P4B & $12.4-$ & $8.5-$ & 17.1 & $(12.6-22.2)$ & $12.9-$ & $9.1-$ & 22.1 & $(17.1-27.4)$ \\
\hline $\mathrm{P} 4 \mathrm{C}$ & $9.2-$ & $0.0-$ & 19.2 & $(14.4-24.4)$ & $7.0-$ & $3.0-$ & 11.9 & $(8.2-16.3)$ \\
\hline $\mathrm{A} 2$ & 0.6 & $0.0-$ & 0.8 & $(0.1-2.5)$ & 1.3 & 0.0 & 0.2 & $(0.0-1.4)$ \\
\hline $\mathrm{A} 3 \mathrm{~A}$ & 0.6 & $0.0-$ & 0.6 & $(0.0-2.2)$ & $2.5+$ & $4.0+$ & 0.5 & $(0.0-2.1)$ \\
\hline A3B & 0.6 & $0.0-$ & 1.1 & $(0.2-3.1)$ & $4.6+$ & 2.0 & 1.4 & $(0.3-3.4)$ \\
\hline A3C & 2.1 & $0.0-$ & 2.1 & $(0.7-4.4)$ & $2.8+$ & 2.0 & 0.9 & $(0.0-2.6)$ \\
\hline $\mathrm{A} 4 \mathrm{~A}$ & 0.4 & $4.3+$ & 0.2 & $(0.0-1.5)$ & 1.2 & $0.0-$ & 0.9 & $(0.0-2.6)$ \\
\hline A4B & 0.4 & $0.0-$ & 0.2 & $(0.0-1.5)$ & 1.3 & $0.0-$ & 0.9 & $(0.0-2.6)$ \\
\hline $\mathrm{A} 4 \mathrm{C}$ & 0.0 & $0.0-$ & 0.4 & $(0.0-1.8)$ & 0.6 & 2.0 & 0.5 & $(0.0-2.1)$ \\
\hline S3A & 0.0 & $0.0-$ & 0.0 & $(0.0-1.1)$ & 1.7 & 2.0 & 0.7 & $(0.1-2.4)$ \\
\hline S3B & 0.0 & $0.0-$ & 0.0 & $(0.0-1.1)$ & $2.9+$ & $3.0+$ & 0.4 & $(0.0-1.7)$ \\
\hline S3C & 0.0 & $0.0-$ & 0.0 & $(0.0-1.1)$ & $3.7+$ & $7.1+$ & 0.4 & $(0.0-1.7)$ \\
\hline S4A & 0.0 & $0.0-$ & 0.0 & $(0.0-1.1)$ & $4.6+$ & $0.0-$ & 2.1 & $(0.7-4.5)$ \\
\hline S4B & 0.0 & $0.0-$ & 0.0 & $(0.0-1.1)$ & 3.4 & 3.0 & 3.9 & $(1.9-6.8)$ \\
\hline S4C & 0.0 & $0.0-$ & 0.0 & $(0.0-1.1)$ & 2.0 & 3.0 & 3.6 & $(1.6-6.3)$ \\
\hline MD & 9.0 & $4.3-$ & 11.3 & $(7.8-15.7)$ & $1.9-$ & $1.0-$ & 17.1 & $(12.7-22.0)$ \\
\hline BP3A & $3.4+$ & 2.1 & 1.1 & $(0.2-3.1)$ & 0.0 & 0.0 & 0.0 & $(0.0-1.0)$ \\
\hline BP3B & 0.6 & $2.1+$ & 0.0 & $(0.0-1.1)$ & 0.0 & 0.0 & 0.0 & $(0.0-1.0)$ \\
\hline BP3C & 0.0 & $0.0-$ & 0.0 & $(0.0-1.1)$ & 0.0 & 0.0 & 0.0 & $(0.0-1.0)$ \\
\hline BP4A & $1.7+$ & $2.1+$ & 0.0 & $(0.0-1.1)$ & 0.0 & 0.0 & 0.0 & $(0.0-1.0)$ \\
\hline BP4B & 0.2 & $0.0-$ & 0.0 & $(0.0-1.1)$ & 0.0 & 0.0 & 0.0 & $(0.0-1.0)$ \\
\hline BP4C & 0.0 & $0.0-$ & 0.0 & $(0.0-1.1)$ & 0.0 & 0.0 & 0.0 & $(0.0-1.0)$ \\
\hline
\end{tabular}

${ }^{\mathrm{I}} \mathrm{P}=$ Pine; $\mathrm{A}=$ Aspen; $\mathrm{S}=$ Spruce $\mathrm{MD}=$ Meadows $\mathrm{BP}=$ Burned Pine

Significance levels for $90 \%$ confidence intervals was determined using the Bonferroni method (Neu et al. 1974, Byers et al. 1984).

$2=<2.5 \mathrm{~cm} \mathrm{DBH} ; 3=12.7-22.9 \mathrm{~cm} \mathrm{DBH} ; 4=>22.9 \mathrm{~cm} \mathrm{DBH}$.

$\mathrm{A}=0-40 \%$ canopy cover; $\mathrm{B}=41-70 \%$ canopy cover; $\mathrm{C}=71-100 \%$ canopy cover.

${ }^{2} \mathrm{~A}$ positive sign $(+)$ indicates significant habitat selection and a negative sign (-) indicates significant habitat avoidance. 
Table 4. Percent availability and use of habitats with and without shrubs selected by doe and buck white-tailed deer during winter and summer in the central Black Hills, South Dakota and Wyoming, 1993-1996.

\begin{tabular}{|c|c|c|c|c|}
\hline & \multicolumn{2}{|c|}{ Does } & \multicolumn{2}{|c|}{ Bucks } \\
\hline & Winter & Summer & Winter & Summer \\
\hline \multicolumn{5}{|l|}{ With Shrubs } \\
\hline \multicolumn{5}{|l|}{ Forest Type } \\
\hline n & 1319 & 1496 & 146 & 181 \\
\hline availability (\%) & 9.6 & 25.2 & 9.6 & 25.2 \\
\hline use $\quad(\%)$ & 20.8 & 53.5 & 26.9 & 44.8 \\
\hline \multicolumn{5}{|l|}{ Overstory/Understory } \\
\hline n & 1000 & 1387 & 124 & 177 \\
\hline availability (\%) & 15.5 & 9.0 & 15.5 & 9.0 \\
\hline use $\quad(\%)$ & 69.6 & 36.6 & 72.6 & 31.7 \\
\hline \multicolumn{5}{|l|}{ Structural Stage } \\
\hline $\mathrm{n}$ & 477 & 786 & 47 & 99 \\
\hline availability (\%) & 29.7 & 38.3 & 29.7 & 38.3 \\
\hline use $\quad(\%)$ & 44.2 & 66.8 & 72.4 & 76.8 \\
\hline \multicolumn{5}{|l|}{ Without Shrubs } \\
\hline \multicolumn{5}{|l|}{ Forest Type } \\
\hline n & 1319 & 1496 & 146 & 181 \\
\hline availability (\%) & 11.6 & 74.8 & 11.6 & 74.8 \\
\hline use $\quad(\%)$ & 6.4 & 46.5 & 1.3 & 55.3 \\
\hline \multicolumn{5}{|l|}{ Overstory/Understory } \\
\hline $\mathrm{n}$ & 1000 & 1387 & 124 & 177 \\
\hline availability $(\%)$ & 78.7 & 76.6 & 78.7 & 76.6 \\
\hline use $\quad(\%)$ & 25.4 & 42.4 & 22.6 & 50.3 \\
\hline \multicolumn{5}{|l|}{ Structural Stage } \\
\hline 11 & 477 & 786 & 47 & 99 \\
\hline availability $(\%)$ & 61.1 & 52.8 & 61.1 & 52.8 \\
\hline use $\quad(\%)$ & 35.2 & 24.2 & 17.0 & 13.1 \\
\hline
\end{tabular}

remaining habitats were used in proportions to their availabilities. During summer, pine/juniper (Fig. 6), aspen/other shrubs, spruce/juniper, and spruce/other shrubs were selected $(\mathrm{P}<0.05)$, whereas burned pine/litter was avoided $(\mathrm{P}<0.05)$ by does and bucks; pine/grass/forb and pine/bearberry was avoided $(\mathrm{P}<0.05)$ by does and spruce/litter was avoided by bucks. All other habitats were used in proportion to their availabilities. Regardless of season, deer of both sexes selected understory range similarly and used types that comprised only $15 \%$ of the landscape on winter range and $9 \%$ of the landscape on summer range.

\section{Structural Stage}

Availability of structural stages differed $\left(\chi^{2}=49.70, \mathrm{df}=25, \mathrm{P}<0.001\right)$ between winter and summer ranges. During winter, structural stage use for does $\left(\chi^{2}=3.86\right.$, df $=25, \mathrm{P}=1.00)$ and bucks $\left(\chi^{2}=21.26, \mathrm{df}\right.$ $=25, \mathrm{P}=0.68)$ did not differ from habitat availability (Table 3 ). During summer, structural stage use differed for does $\left(\chi^{2}=\right.$ 49.63, $\mathrm{df}=25, \mathrm{P}<0.001)$ and bucks $\left(\chi^{2}=\right.$ 39.75 , df $=25, \mathrm{P}<0.001)$ compared to habitat availability.

During winter, deer of both sexes spent $>80 \%$ of their time in pine stands (Fig. 7) Wyoming, 1993-1996. medium age with medium to heavy canopies. Most of the remaining time was spent in stands of aspen and spruce (Fig. 8) regardless of canopy cover. Overall, deer selected structural stages that comprised only $30 \%$ of the winter range and $38 \%$ of the summer range.

\section{Discussion}

Clearly, in the central Black Hills, deer spent most of their time in and were primarily supported by pine forested range, which dominates the landscape. However, the structural stage classification of the Black Hills National Forest Inventory System does not lend itself to clearly explaining deer/habitat relationships. Selection of specific habitats by deer was much better explained by the availability of understory plant communities, which provides, thermal cover, escape cover, and food. Therefore, we more closely examined these relationships by comparing deer use of habitats in relation to the presence/absence of shrubs (Table 4). On winter range, deer use of forested stands with shrubs was 1.5 to 4.7 times greater than the availability of those habitats. On summer range, the relative difference between habitats containing shrubs selected by deer compared to the availability of those habitats ranged from 1.8 to 4.1 times greater than those habitats without shrubs.

Because hunter success (McPhillips and

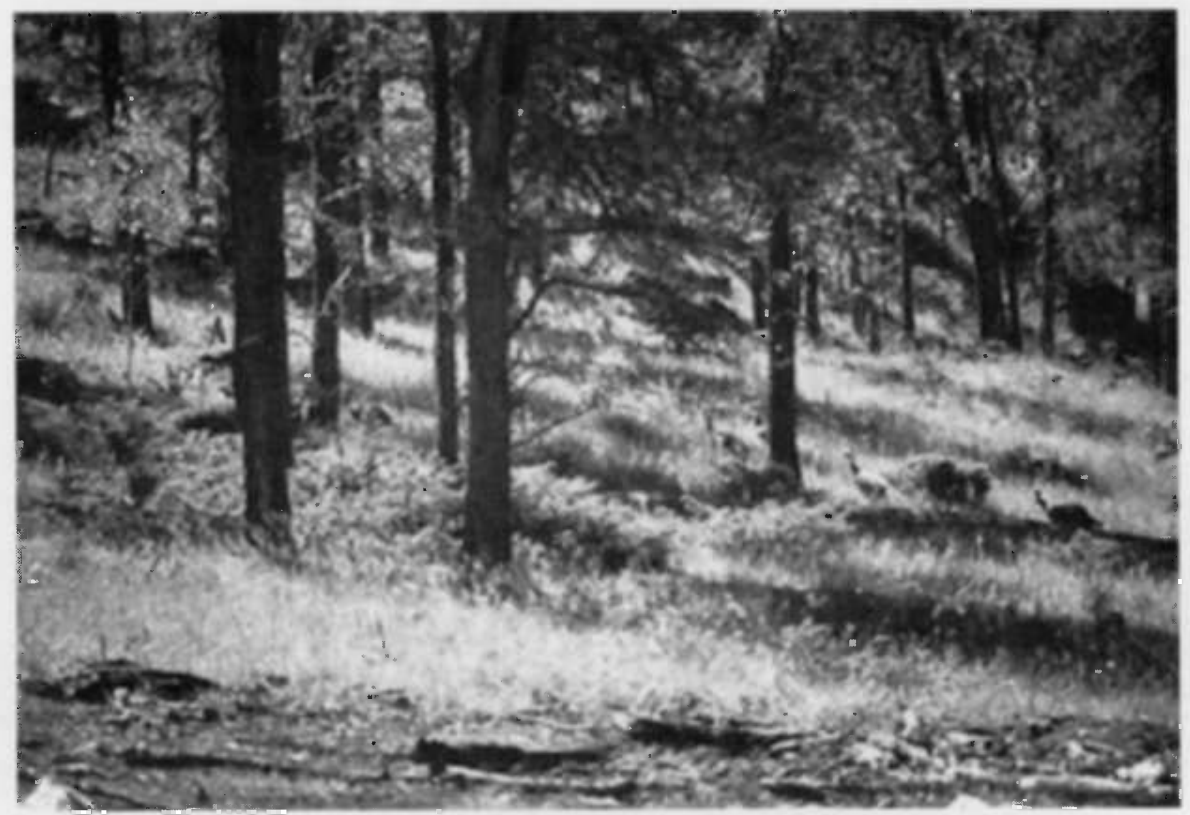

Fig. 6. Pine/juniper habitat on summer range in the central Black Hills, South Dakota and 


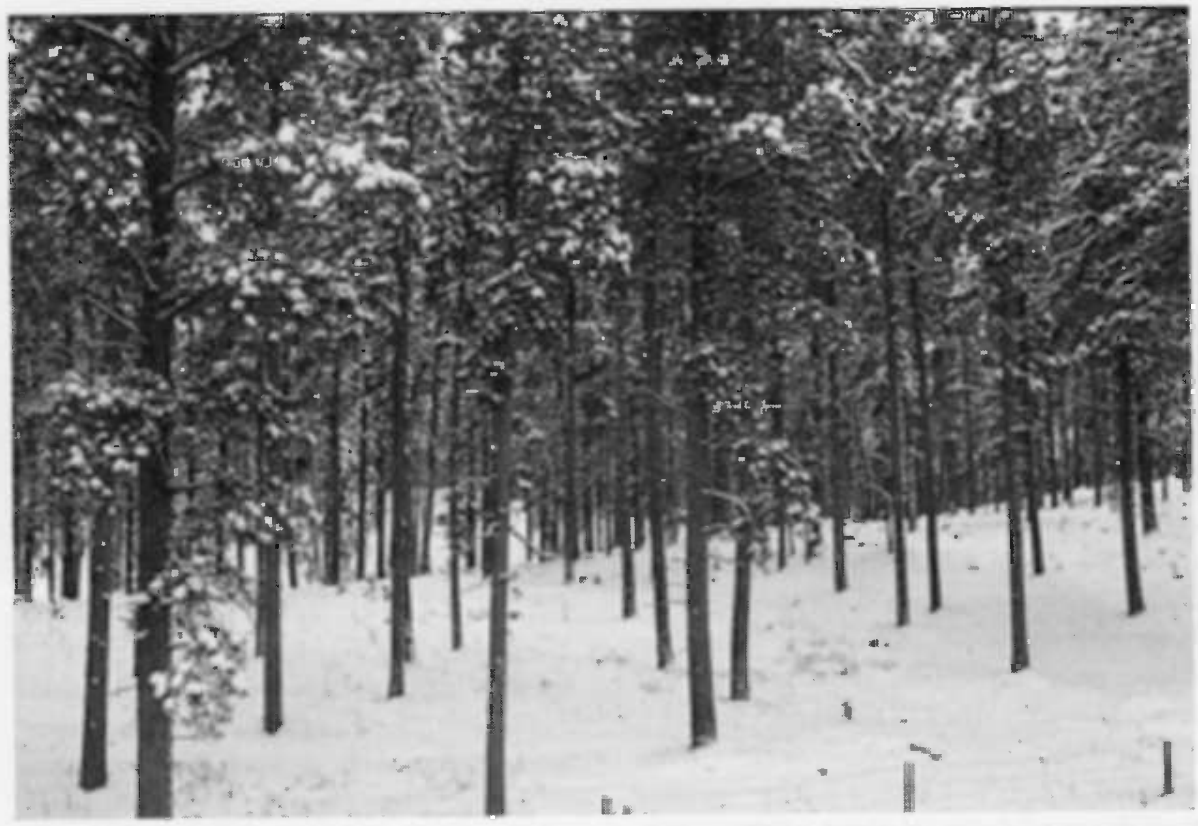

Fig. 7. Pine habitat on winter range in the central Black Hills, South Dakota and Wyoming, 1993-1996.

Rice 1991), deer reproductive success (Rice 1984, Hauk 1987, McPhillips 1990, Hippensteel 2000), and fawn survival (Rice 1979, Benzon 1998) have not increased with herd reductions, Griffin et al. (1992) reported that most management agencies believe the long term population decline and low productivity affecting central Black Hills white-tailed deer are directly related to habitat deterioration. In the central Black Hills, Hippensteel (2000) determined that winter range diets of white-tailed deer were composed of approximately $40 \%$ ponderosa pine, $30 \%$ grass, $20 \%$ shrub, and $5 \%$ forbs, which supports the contention that poor quality habitat is responsible for the long term population decline of white-tailed deer in the central Black Hills.

\section{Winter Range}

During winter, pine habitats that contained a shrub component were selected by white-tailed deer. We believe these

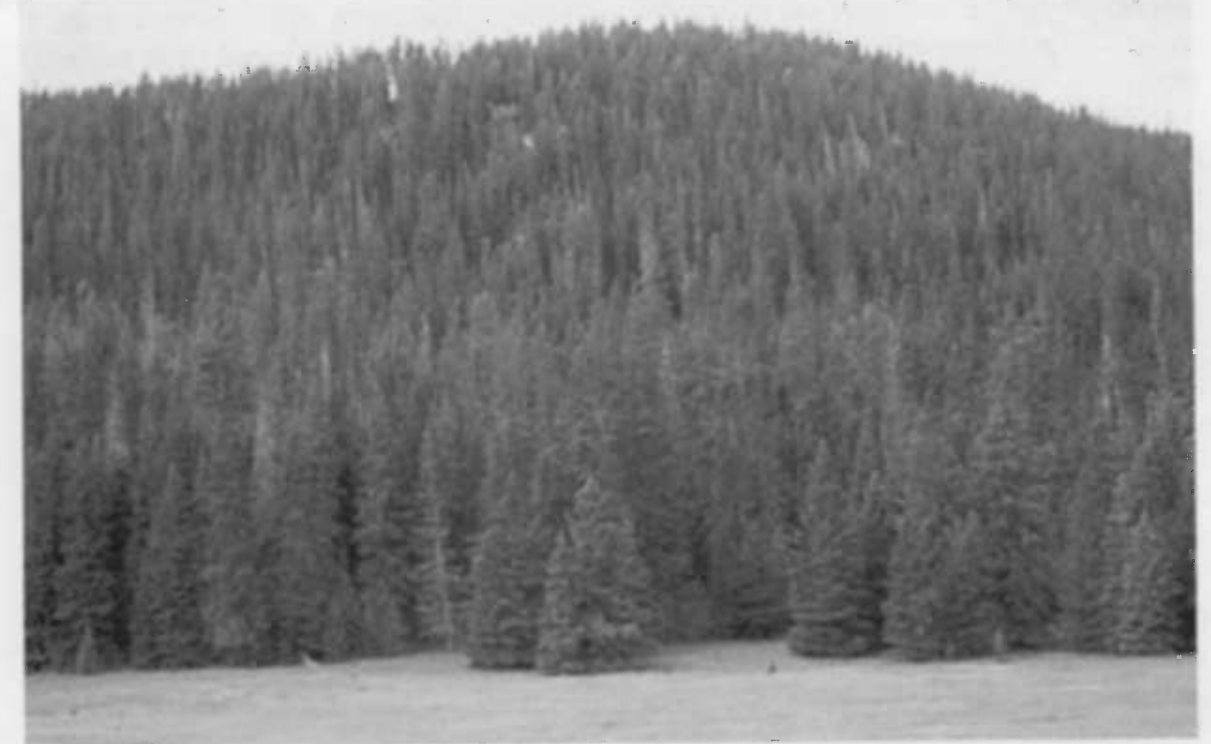

Fig. 8. Spruce habitat on summer range in the central Black Hills, South Dakota and Wyoming, 1993-1996. pine stands were selected because of the thermoregulatory benefits they provide (Kennedy 1992). As air temperature declines, heat loss from the animal's surface increases due to convection (Moen 1968). Therefore, deer may be experiencing a physiological benefit by occupying habitats on winter range that contain understory and overstory vegetation; habitats with high thermal cover characteristics (Moen 1976, Parker and Gillingham 1990). In addition to thermoregulatory benefits, we believe deer are selecting areas that contain shrubs (i.e., bearberry, juniper, and snowberry) because they are important sources of forage necessary to winter survival of deer in the central Black Hills (Hill 1946, Schneeweis et al. 1972, Schenck et al. 1972). This is further supported because pine habitats dominated by snowberry, juniper, and bearberry are relatively rare in this region of the Black Hills but were sought out and selected by deer. Additionally, habitats with shrubs were selected at levels 1.5 to 4.7 times greater than the availability of those habitats. Results indicate that approximately $80 \%$ of the habitat in the central Black Hills does not contain shrubs and thus, is not acceptable for deer.

Burned pine forests were selected by white-tailed deer during winter but not during summer (burned habitats are rare on summer range). Burning speeds organic matter decomposition rates and releases nutrients into the environment, promoting the production of forage higher in protein (Einarsen 1946, Swank 1956, Sieg and Severson 1996). Similarly, researchers have concluded that burning in an unthinned ponderosa pine stand removed the litter component, initially increased the nutrient value of the herbaceous vegetation, and stimulated growth of grasses, forbs, and shrubs, thereby increasing the quality of the vegetation (Krefting 1962, Pearson et al. 1972, Harestad and Rochelle 1982). However, most larger burned areas within the central Black Hills are $>40$ years post-burn. Browse production increases for 3-5 years following a burn before returning to pre-burn levels (Lay 1957, Taber and Dasmann 1957, Pearson et al. 1972). Consequently, deer use of burned areas may have been detected because forage species (e.g., bearberry, snowberry, and juniper) important to deer (Hill 1946, Schneeweis et al. 1972, Schenck et al. 1972) are essentially absent in the dominant unburned pine communities of the central Black Hills. 
On winter range, does selected open burned pine and pine deciduous habitats, whereas bucks selected closed pine stands and avoided meadows. Interestingly, does were located feeding (52\%) and bedding $(48 \%)$ similar proportions of time, whereas bucks were located bedding $(64 \%)$ more often than feeding $(36 \%)$. Additionally, doe home ranges were about twice as large on winter (202.9 ha) range compared to summer (130.9 ha) range (Griffin et al. 1999). Larger winter home ranges and increased time spent foraging by does compared to bucks may be a function of the does requirement for greater quantities of forage during winter gestation, whereas bucks have lower energy demands during this period and spend more time loafing. Although, white-tailed deer normally reduce food intake during winter (Short et al. 1969, Schultz et al. 1993), we believe that adequate forage is limited (Spalinger et al. 1993) in this region. For example, on winter range, aspen stands represent $<5 \%$ of the available habitat, understory shrubs (i.e., bearberry, juniper, and snowberry) and forbs represent $<30 \%$, and litter comprises $57 \%$ of the available ground cover (DePerno 1998, DePerno et al. 2000). Furthermore, $>90 \%$ of the forest stands lack significant understory vegetation or tall shrub saplings (DePerno 1998, DePerno et al. 2000). Poor quality habitat and limited availability of deciduous and shrub habitats (DePerno 1998), high doe mortality in early spring (i.e., $53.2 \%$ of radiocollared doe mortality occurred in spring, DePerno 1998, DePerno et al. 2000), an adult reproductive rate of 1.33 fawns/doe, and a winter range diet of $40 \%$ ponderosa pine (Hippensteel 2000) indicate that does are nutritionally stressed on winter range in the central Black Hills.

\section{Summer Range}

During summer, deer selected deciduous forests that contained shrubs. Hill (1946) concluded that aspen and associated shrubs were important and highly palatable to white-tailed deer during summer in the northern Black Hills. Aspen areas have been determined to be important for both escape cover and forage for white-tailed deer throughout the Black Hills (Kranz 1971, Schneeweis et al. 1972, Schenck et al. 1972, Kranz and Linder 1973, Kennedy 1992, Stefanich 1995). However, habitats dominated by deciduous cover $(<12 \%)$ are limited on summer range in the central Black Hills (DePerno 1998, DePerno et al. 2000). Furthermore, grass and forbs composed $<30 \%$ of ground cover and shrubs composed $<21 \%$ of the available ground cover. These data coupled with approximately $48 \%$ litter cover indicate that grass, forb, and shrub forages are lacking on summer range in the central Black Hills (DePerno 1998, DePerno et al. 2000). Additionally, tall shrub sapling densities were nearly three times lower in the central Black Hills (1113.03 + 321.07 stems/ha) compared to the northern Black Hills $(3246.84+164.87$ stems/ha; Hippensteel 2000), which suggests the central Black Hills lack sufficient understory vegetation and escape cover that are important for white-tailed deer (DePerno 1998). Furthermore, habitats with shrubs were selected at levels 1.8 to 4.1 times greater than the availability of those habitats, suggesting that much of the habitat in the central Black Hills does not contain shrubs and is not acceptable habitat for deer.

During summer, structural stages with $71-100 \%$ canopy cover, were selected by white-tailed deer. Dense overhead canopy cover provides a cool environment, which may allow deer to avoid heat stress (Bunnell et al. 1986, Hoffman and Alexander 1987) and reduce cutaneous water loss (Parker and Robbins 1984). Additionally, deer selected the relatively open aspen and spruce stands, suggesting that habitats containing understory vegetation were important. Deciduous habitats and habitats with shrubs were likely selected because they are important sources of forage and provide horizontal cover for predator avoidance (DePerno 1998).

In the central Black Hills, spring migration of white-tailed deer from low elevation winter ranges to high elevation summer ranges generally occurs between 17 and 23 May (DePerno 1998, Griffin et al. 1999). This is about 3 weeks prior to the peak date of parturition, which occurs approximately 11 June (Benzon 1998). On summer range, does selected deciduous habitats that provide horizontal cover (DePerno 1998) and an abundant supply of forage for fawning (Smith and LeCount 1979, King and Smith 1980, Bowyer and Bleich 1984, Riley and Dood 1984, Huegel et al. 1986, Loft et al. 1987, Fox and Krausman 1994, Main and Coblentz 1996, Uresk et al. unpublished data). Horizontal cover is important to fawns; does seek isolation in areas where hiding cover and forage are abundant (King and Smith 1980, DePerno 1998). Interestingly, does were located feeding (37\%) more than bucks (14\%). Therefore, we postulate that in the central Black Hills, does migrate from winter to summer range just prior to parturition to give birth in areas that provide thermal cover, maximum forage characteristics, and concealment cover for fawns, whereas bucks migrate to sites with high quality forage on summer range to maximize body condition.

\section{Summary and Management Implications}

Results of this study indicate that deciduous cover types and habitats with understory vegetation were important to whitetailed deer in the central Black Hills. Sieg and Severson (1996) hypothesized that white-tailed deer densities in the Black Hills have been reduced due to the regeneration of ponderosa pine stands, prevention of natural fires, and elimination of man-made fires. Absence of fire has substantially increased ponderosa pine while hindering new growth with negative consequences for habitat diversity, wildlife, and livestock interests (Richardson and Petersen 1974, Sieg and Severson 1996). Reducing coniferous overstory vegetation in and around aspen stands could increase understory vegetation and forage diversity, which would enhance opportunities for herbivores to encounter higher quality plants or plant parts (Ffolliot and Clary 1982, McConnell and Smith 1970, Severson and Uresk 1988). Furthermore, if areas are logged first and then burned, forbs and shrubs will increase and sprout growth of some species (e.g., chokecherry, snowberry, and willow; Wright and Bailey 1982) may be doubled (Krefting 1962, Harestad and Rochelle 1982). We recommend that agencies responsible for habitat manipulation/management in the central Black Hills give consideration to habitat treatments or modifications of on-going management (e.g., aspen regeneration, logging, prescribed burning) that benefit white-tailed deer by significantly increasing deciduous habitats and understory vegetation on both winter and summer ranges in the central Black Hills.

Elk and livestock interests may be contributing to deer decline in the central Black Hills (DePerno 1998, DePerno et al. 2000) through competition for forage 
(Jenks et al. 1996, Hippensteel 2000), habitat disturbance (Loft et al. 1987), displacement (Crawford 1984, Loft et al. 1987, Loft 1988, Kie at al. 1991), survival (Smith 1982), and length of time on grazing allotments. Low to moderate cattle regimes may be beneficial to elk and deer (Skovlin et al. 1968). However, high dietary overlap between deer and elk (49\%), high pine consumption by deer (Hippensteel 2000), and length of cattle grazing (i.e., in the central Black Hills livestock grazing occurs from 1 June to 31 October) suggest the cattle grazing regime presently practiced in the Black Hills is excessive and incompatible with improving the white-tailed deer herd in the central Black Hills. We recommend the Forest Service re-evaluate their current grazing allotment (e.g., number of cattle and length of time) system as it relates to availability of deciduous and shrub habitats for white-tailed deer in the central Black Hills.

\section{Literature Cited}

Alldredge, J. R. and J. T. Ratti. 1986. Comparison of some statistical techniques for analysis of resource selection. J. Wildl. Manage. 50:157-165.

Alldredge, J. R. and J. T. Ratti. 1992. Further comparison of some statistical techniques for analysis of resource selection. J. Wildl. Manage. 56:1-9.

Apps, C. D., B. N. McLellan, T. A. Kinley, and J. P. Flaa. 2001. Scale-dependent habitat selection by mountain caribou, Columbia Mountains, British Columbia. J. Wildl. Manage. 65:65-77.

Beier, P. and D. R. McCullough. 1988. Motion-sensitive radio collars for estimating white-tailed deer activity. J. Wildl. Manage. 52:11-13

Benzon, T. A. 1998. Mortality and habitat use of white-tailed deer fawns in the central Black Hills, South Dakota 1994-1998. Pittman-Robertson Game Rep. W-75-R-34. S. D. Dept. of Game, Fish and Parks, Pierre, S.D. 43pp.

Bowyer, R. T. and V. C. Bleich. 1984. Effects of cattle grazing on selected habitats of southern mule deer. Calif. Fish and Game. 70:240-247.

Bunnell, F.L., K.L. Parker, L.L. Kremsater, and F.W. Hovey. 1986. Thermoregulation and thermal cover of deer and elk on Vancouver Island: problem analysis. British Columbia Ministries of Environment and Forests. IWIFR-28. Victoria, British Columbia.

Buttery, R. F. and B. C. Gillam. 1983. Forest ecosystems. pp 34-71 In: R. L. Hoover and D.L. Wills, eds. Managing forested lands for wildlife. Colo. Div. of Wildl. in cooperation with USDA Forest Serv., Rocky Mountain Region, Denver, Colo.. 459 pp.
Byers, C. R., R. K. Steinhorst, and P. R. Krausman. 1984. Clarification of a technique for analysis of utilization-availability data. J. Wildl. Manage. 48:1050-1053.

Clover, M. R. 1956. Single-gate deer trap. Calif. Fish and Game. 42:199-201.

Crawford, H. S. 1984. Habitat management Pages 629-646 in L. K. Halls, editor. Whitetailed deer: ecology and management. Stackpole, Harrisburg, Penns., USA.

Daubenmire, R. F. 1959. A canopy-coverage method of vegetational analysis. Northwest Sci. 33:43-64.

DePerno, C. S. 1998. Habitat selection of a declining white-tailed deer herd in the central Black Hills, South Dakota and Wyoming. Ph.D. Diss., S. Dak. State Univ., Brookings, S. Dak. USA.

DePerno, C. S., S. L. Griffin, J. A. Jenks, and L. A. Rice. 1997. Unusual migration by a white-tailed deer fawn. Prairie Nat. 29:93-97.

DePerno, C. S., J. A. Jenks, S. L. Griffin, and L. A. Rice. 2000. Female survival rates in a declining white-tailed deer population. Wildl. Soc. Bull. 28:1030-1037.

Edwards, R. L. 1969. Archaeological use of the Universal Transverse Mercator grid. American Antiquity 34:180-182.

Einarsen, A. S. 1946. Crude protein determination of deer food as an applied management technique. Trans. North Amer. Wildl Conf. 11:309-312.

Ffolliot, P. F. and W. P. Clary. 1982. Understory-overstory vegetation relationships: an annotated bibliography. USDA For Serv. Gen. Tech. Rep. INT-136. Intermtn. For. and Range Exp. Sta., Ogden, Utah. $33 \mathrm{pp}$.

Ford-Robertson, F. C., Ed. 1971. Terminology of forest science technology practice and products: English language version. Multilingual For. Term. Ser. 1. Soc. Amer. For., Washington D.C. 349pp.

Fox, K. B., and P. R. Krausman. 1994. Fawning habitat of desert mule deer Southwest. Nat. 39:269-275.

Griffin, S. L. 1994. Seasonal movements and home range of white-tailed deer in the central Black Hills, South Dakota, 1993. PittmanRobertson Report W-75-R-35. South Dakota Dept. of Game, Fish and Parks, Pierre, S. Dak. 13pp.

Griffin, S. L., J. F. Kennedy, L. A. Rice, and J. A. Jenks. 1992. Movements and habitat use of white-tailed deer in the northern Black Hills, S. Dak., 1991. Pittman-Robertson Report W-75-R-33. South Dakota Dept. of Game, Fish and Parks, Pierre, S. Dak. 21pp.

Griffin, S. L., L. A. Rice, C. S. DePerno, and J. A. Jenks. 1999. Seasonal movements and home ranges of white-tailed deer in the central Black Hills, South Dakota and Wyoming, 1993-97. S. Dak. Dept. of Game, Fish and Parks, Pittman-Robertson Game Rep. W-75R-34, Pierre, S. Dak., USA.

Griffin, S. L., C. S. DePerno, J. A. Jenks, L. A. Rice, and D. A. Flory. 1995. Capture success of white-tailed deer in the central Black Hills, South Dakota. S. Dak. Acad. Sci. 74:71-76.
Grubb, T. G. and W. L. Eakle. 1988. Recording wildlife locations with the Universal Transverse Mercator (UTM) Grid System. USDA For. Serv. Res. Pap. RM483. Rocky Mt. For. and Range Exp. Sta., Ft. Collins, Colo.. 3pp.

Hansen, M. C., G. W. Garner, and S. G. Fancy. 1992. Comparison of 3 methods for evaluating activity of Dall's sheep. J. Wildl. Manage. 56:661-668.

Harestad, A. S., and J. A. Rochelle. 1982. Old-growth forests and black-tailed deer on Vancouver Island. Trans. North Amer. Wildl. Nat. Resour. Conf. 47:363-373.

Hauk, R. W. 1987. Deer management surveys, 1987. Pittman-Robertson Rept. W-95-R-22. S. Dak. Dept. of Game, Fish and Parks, Pierre, S. Dak. 40pp.

Hill, R. R. 1946. Palatability ratings of Black Hills plants for white-tailed deer. J. Wildl. Manage. 10:47-54.

Hippensteel, B. A. 2000. Factors affecting nutritional condition of white-tailed deer in the central Black Hills, South Dakota. M.S. Thesis, S. Dak. State Univ., Brookings, S. Dak., USA.

Hoffman, G. R. and R. R. Alexander. 1987. Forest vegetation of the Black Hills National Forest of South Dakota and Wyoming: a habitat type classification. USDA Res. Pap. RM-276. Rocky Mt. For. and Range Exp. Sta., Fort Collins, Colo. 48pp.

Hovind, H. J. and C. E. Reick. 1970. Basal area and point sampling: interpretation and application. Wis. Dept. Nat. Res. Tech. Bull. 23. $52 \mathrm{pp}$.

Huegel, C. N., R. B. Dahlgren, and H. L. Gladfelter. 1986. Bedsite selection by whitetailed deer fawns in Iowa. J. Wildl. Manage. 50:474-480.

Jelinski, D. E. 1991. On the use of chi-square analyses in studies of resource utilization. Can. J. For. Res. 21:58-65.

Jenks, J.A., D.M. Leslie, Jr., R.L. Lochmiller, M. A. Melchiors, and F. McCollum, III. 1996. Competition in sympatric whitetailed deer and cattle populations in southern pine forests of Oklahoma and Arkansas, USA. Acta Theriologica 41:287B306

Kennedy, J. F. 1992. Habitat selection by female white-tailed deer in the northern Black Hills, South Dakota and Wyoming. M.S. Thesis, South Dakota State Univ. Brookings, S. Dak. 65pp.

Kernohan, B. J., J. A. Jenks, D. E. Naugle, and J. J. Millspaugh. 1996. Estimating 24-h habitat use patterns of white-tailed deer from diurnal use. J. Environ. Manage. 48:299-303.

Kie, J. G., C. J. Evans, E. R. Loft, and J. W. Menke. 1991. Foraging behavior by mule deer: the influence of cattle grazing. J. Wild. Manage. 55:665-674.

King, M. M. and H. D. Smith. 1980. Differential habitat utilization by the sexes of mule deer. Great Basin Nat. 40:273-281.

Kranz, J. J. 1971. A comparison of aspen and pine communities in the northern Black Hills. M.S. Thesis, South Dakota State Univ., Brookings, S. Dak. 52 pp.

Kranz, J. J. and R. L. Linder. 1973. Value of Black Hills forest communities to deer and cattle. J. Range Manage. 26:263-265. 
Krefting, L. W. 1962. Use of silvicultural techniques for improving deer habitat in the lake states. J. For. 60:40-42.

Lay, D. W. 1957. Browse quality and the effects of prescribed burning in southern pine forests. J. For. 55:342-347.

Lemmon, P. E. 1956. A spherical densiometer for estimating forest overstory density. For. Sci. 2:314-320.

Loft, E. R. 1988. Habitat and spatial relationships between mule deer and cattle in a Sierra Nevada forest zone. Diss., Univ. of California, Davis, Calif., USA.

Loft, E. R., J. W. Menke, J. G. Kie, and R. C. Bertram. 1987. Influence of cattle stocking rate on the structural profile of deer hiding cover. J. Wildl. Manage. 51:655-664.

Main, M. B. and B. E. Coblentz. 1996. Sexual segregation in Rocky Mountain mule deer. $\mathbf{J}$ Wildl. Manage. 60:497-507.

Marcum, C. L. and D. O. Loftsgaarden. 1980. A nonmapping technique for studying habitat preferences. J. Wildl. Manage. 44:963-968

Martin, W. E. and R. L. Gum. 1978 Economic value of hunting, fishing, and general rural outdoor recreation. Wildl. Soc. Bull. 6:3-7.

McClean, S. A., M. A. Rumble, R. M. King, and W. L. Baker. 1998. Evaluation of resource selection methods with different definitions of availability. J. Wildl. Manage. 62:793-801.

McConnell, B. R., and J. G. Smith. 1970. Response of understory vegetation to ponderosa pine thinning in eastern Washington. J. Range Manage. 23:208-212

McIntosh, A. C. 1949. A botanical survey of the Black Hills of South Dakota. Black Hills Engin. 28:1-74.

McPhillips, K. 1990. Deer management surveys, 1989. Pittman-Robertson Report W-95R-24. South Dakota Department of Game, Fish and Parks, Pierre, S. Dak. 40pp.

McPhillips, K. and L. A. Rice. 1991. Deer management surveys, 1991. South Dakota Department of Game, Fish and Parks, Pittman-Robertson Game Report W-95-R-25, Pierre, S. Dak. 49 pp.

Moen, A. N. 1968. Surface temperatures and radiant heat loss from white-tailed deer. J. Wildl. Manage. 32:338-344.

Moen, A. N. 1976. Energy conservation by white-tailed deer in winter. Ecol. 57:192-198.

Nelson, B. E. 1995. Use of a Geographic Information system for determining whitetailed deer habitat use in the Northern Black Hills of South Dakota and Wyoming. M.S. Thesis, South Dakota State Univ., Brookings, S. Dak. USA.

Neu, C. W., C. R. Byers, and J. M. Peek. 1974. A technique for analysis of utilizationavailability data. J. Wildl. Manage. 38:541-545.

Orr, H. K. 1959. Precipitation and streamflow in the Black Hills. USDA Station Pap. 44. Rocky Mt. For. and Range Exp. Station, Fort Collins, Colo. 25pp.

Ozoga, J. J., L. J. Verme, and C. S. Bienz. 1982. Parturition behavior and territoriality in white-tailed deer: impact on neonatal mortality. J. Wildl. Manage. 46:1-11.
Parker, K. L. and M. P. Gillingham. 1990. Estimates of critical thermal environments for mule deer. J. Range. Manage. 43:73-80.

Parker K. L., and C. T. Robbins. 1984. Thermoregulation in mule deer and elk. Can. J. Zool. 62:1409-1422.

Pearson, H. A., J. R. Davis, and G. H. Shubert. 1972. Effects of wildfire on timber and forage production in Arizona. J. Range Manage. 25:250-253.

Petersen, L.E. 1984. Northern Plains. pp. 441-448 In: L. K. Halls, ed. White-tailed deer: ecology and management. Stackpole Books, Harrisburg, Penn. 870pp.

Progulske, D. R. and T. S. Baskett. 1958. Mobility of Missouri deer and their harassment by dogs. J. Wildl. Manage. 22:184-192.

Richardson, A. H., and L. E. Peterson. 1974 History and Management of South Dakota Deer. South Dakota Dept. Game, Fish and Parks Publ. Bull. No. 5. Pierre, S. Dak. $113 \mathrm{pp}$.

Riley, S. J. and A. R. Dood. 1984. Summer movements, home range, habitat use, and behavior of mule deer fawns. J. Wildl. Manage. 48:1302-1310.

Rice, L. A. 1979. Mortality rates of fawn age class in South Dakota deer populations, 1978-1979. Pittman-Robertson Report W75-R-21. S. Dak. Department Game, Fish and Parks, Pierre, S. Dak. 17 pp.

Rice, L. A. 1984. Fawn mortality rates in South Dakota deer populations, 1977-1981. Pittman-Robertson Report W-75-R-26. S. Dak. Dept. Game, Fish and Parks, Pierre, S. Dak. 45pp.

Rumble, M. A. and S. H. Anderson. 1992. Stratification of habitats for identifying habitat selection by Merriam's Turkeys. Great Basin Nat. 52:139-144.

Rumble, M. A. and S. H. Anderson. 1993. Habitat selection of Merriam's turkey (Meleagris gallopavo merriami) hens with poults in the Black Hills, S. Dak. Great Basin Nat. 53:131-136.

Schenck, T. E., III, R. L. Linder, and A. H. Richardson. 1972. Food habits of deer in the Black Hills, Part II: Southern Black Hills. South Dakota Agr. Exp. Sta. Bull. 606, S. Dak. State Univ., Brookings S. Dak. 35pp.

Schneeweis, J. C., K. E. Severson, and L. E. Petersen. 1972. Food habits of deer in the Black Hills, Part I: Northern Black Hills. South Dakota Agr. Exp. Sta. Bull. 606, South Dakota State Univ., Brookings, S. Dak. 35 pp.

Schultz, S. R., M. K. Johnson, and A. E. Hindrichs. 1993. Effects of spring/summer body mass gain and sex ratio on fall/winter body mass loss of adult, male white-tailed deer. Small Rum. Res. 10:183-188.

Severson, K. E. and D. W. Uresk. 1988. Influence of ponderosa pine overstory on forage quality in the Black Hills, South Dakota. Great Bas. Nat. 48:78-82.

Short, H. L., J. D. Newsom, G. L. McCoy, and J. F. Fowler. 1969. Effects of nutrition and climate on southern deer. Trans. North Amer. Wildl. Conf. 34:137-146.

Sieg, C. H. and K. E. Severson. 1996. Managing habitats for white-tailed deer in the Black Hills and Bear Lodge Mountains of South Dakota and Wyoming. USDA For. Serv. Gen. Tech. Rep. RM-GTR-274. Rocky Mt. For. and Range Exp. Station, Fort Collins, Colo. 24pp.
Skovlin, J. M., P. J. Edgerton, and R. W. Harris. 1968. The influence of cattle management on deer and elk. Trans. of the North Amer. Wildl. and Nat. Res. Conf. 33:169-181.

Smith, D. M. 1962. The practice of silviculture, 7th edition. John Wiley and Sons, Inc. New York, N.Y. 578 pp.

Smith, W. P. 1982. Status and habitat use of Columbian white-tailed deer in Douglas County, Oregon, Diss., Oregon State Univ., Corvallis, Ore., USA.

Smith, R. H. and A. LeCount. 1979. Some factors affecting survival of desert mule deer fawns. J. Wildl. Manage. 43:657 $\neq 665$.

Spalinger, D. E., C. T. Robbins, and T. A. Hanley. 1993. Adaptive rumen function in elk (Cervus elaphus nelsoni) and mule deer (Odocoileus hemionus hemionus). Can. J. Zool. 71:601-610.

Stefanich, M. R. 1995. Movements and habitat use of white-tailed deer in the northwestern Black Hills of Wyoming and South Dakota. M.S. Thesis, Univ. of Wyo., Laramie, Wyo. $46 \mathrm{pp}$.

Swank, W. G. 1956. Protein and phosphorous content of browse plants as an influence on southwestern deer herd levels. Trans. North Amer. Wildl. Conf. 21:141-158.

Taber, R. D. and R. F. Dasmann. 1957. The dynamics of three natural populations of the deer Odocoileus hemionus columbianus. Ecol. 38:233-246.

Thilenius, J. F. 1972. Classification of deer habitat in the ponderosa pine forest of the Black Hills, South Dakota. USDA For. Serv. Res. Pap. RM-91. Fort Collins, Colo. 28 pp.

Tierson, W. C., G. F. Mattfield, R. W. Sage, Jr., and D. F. Behrend. 1985. Seasonal movements and home ranges of white-tailed deer in the Adirondacks. J. Wildl. Manage. 49:760-769.

Turner, R. W. 1974. Mammals of the Black Hills of South Dakota and Wyoming. Misc. Publ. Mus. Nat. Hist. University of Kansas. $178 \mathrm{pp}$.

United States Fish and Wildlife Service. 1993. National Survey of Fishing, Hunting, and Wildlife-Associated Recreation. U.S. Govern. Printing Off., Washington D.C. 41 pp.

Wallace, M. S., H. L. Stribling, and H. A. Clonts. 1991. Effects of hunter expenditure distribution on community economics. Wildl. Soc. Bull. 19:7-14.

Weckerly, F. W. 1993. Intersexual resource partitioning in black-tailed deer: a test of the body size hypothesis. J. Wildl. Manage. 57:475-494.

White, G. C. and R. A. Garrott. 1990. Analysis of wildlife radio-tracking data. Academic Press, New York, N.Y. 383 pp.

Wilkinson, L. 1990. Systat: the system for statistics. Systat, Inc. Evanston, Ill. 750 pp.

Williamson, L. L. and G. L. Doster. 1981. Socioeconomic aspects of white-tailed deer diseases. pp 434-439 In: W.R. Davidson, ed. Diseases and parasites of white-tailed deer. Tall Timbers research Station, Tallahassee, Fla. 472 pp.

Wright, H. A. and A. W. Bailey. 1982. Fire Ecology. John Wiley \& Sons, New York, N.Y. 501pp. 